VAT BASE BROADENING, SELF SUPPLY, AND THE INFORMAL SECTOR

\author{
John Piggott
}

John Whalley

Working Paper 6349 
NBER WORKING PAPER SERIES

\title{
VAT BASE BROADENING, SELF SUPPLY, AND THE INFORMAL SECTOR
}

\author{
John Piggott \\ John Whalley \\ Working Paper 6349 \\ http://www.nber.org/papers/w6349

\section{NATIONAL BUREAU OF ECONOMIC RESEARCH 1050 Massachusetts Avenue \\ Cambridge, MA 02138 \\ January 1998}

The second author acknowledges financial support from the Social Sciences and Humanities Research Council (SSHRC). This is a substantial elaboration of an earlier version of this paper, which was presented at the Warwick Summer Workshop, July 1995 and at Western Ontario in Spring 1996. We are grateful to Jim Davies, Carlo Perroni, Keshab Bhattarai, and to workshop participants for comments; and to Aled Abiorwerth and Chris Dawkins for research support. Any opinions expressed are those of the authors and not those of the National Bureau of Economic Research.

(C) 1998 by John Piggott and John Whalley. All rights reserved. Short sections of text, not to exceed two paragraphs, may be quoted without explicit permission provided that full credit, including (0) notice, is given to the source. 
VAT Base Broadening, Self Supply, and The Informal Sector

John Piggott and John Whalley

NBER Working Paper No. 6349

January 1998

\begin{abstract}
We develop a general equilibrium tax model to evaluate the impacts of equal yield base broadening in indirect taxes from high rate narrow based (typically manufactures) taxes to broad based taxes (including services) such as a VAT. We capture differences in choice of mode of supply between market goods, such as manufactures, which cannot be supplied other than through the market, and self-suppliable services and informal sector supplied products. Using this formulation, we are able to provide numerical examples of welfare worsening VAT base broadening, which expands the tax base from market based manufactures, in which there are few (or no) non taxed supply possibilities, to all goods and services where such possibilities exist. We show that the usual presumption that there are welfare benefits from equal yield VAT base broadening breaks down once tax induced increases in self supply of previously non taxed goods and services and in informal sector activity (in small scale construction and other areas) are taken into account. Moreover, since untaxed informal sector supply is typically from lower income to higher income households, they gain as comparable informal sector activity is taxed under the base broadening change. We provide a calibrated version of the model, which captures Canadian base broadening accompanying the introduction of the Canadian VAT (GST) in 1990. Results show the change to have been welfare worsening in aggregate but progressive; opposite to conventional belief. Aggregate welfare losses increase sharply if pre-existing income taxes enter the analysis, since VAT induced supply side losses compound with the income tax, while consumption side tax rate variance reducing gains do not.
\end{abstract}

John Piggott

School of Economics

University of New South Wales

PO Box 1

Kensington, NSW 2033

AUSTRALIA
John Whalley

Department of Economics

Social Science Centre

University of Western Ontario

London, Ontario N6A 5C2

CANADA

and NBER

whalley@sscl.uwo.ca 


\section{INTRODUCTION}

Among public finance economists, broadly based sales or value added taxes are generally thought to dominate narrowly based higher rate taxes on efficiency grounds. This is because uniform rate taxes on a broad base are viewed as both removing intercommodity distortions, and minimizing distortions of labour supply. While optimal commodity tax literature suggests that it is possible for non-uniform tax rates to be optimal if the various taxed commodities are either substitutes or complements of leisure, ${ }^{2}$ such results are generally given little prominence by policy oriented public financiers. They maintain their advocacy of broadly based taxes on the grounds that the relevant cross elasticities are still largely unknown, that simplicity in tax design is a virtue, and that separability is a reasonable working hypothesis. ${ }^{3}$

This paper reopens the debate on the merits of broadly based indirect taxes by focusing on tax induced effects on self supply and on informal sector (underground) activities ${ }^{4}$ which become tax preferred as VAT base broadening occurs. It builds on the observation that in a

${ }^{2}$ Sadka (1977), in a well known paper shows that separability in preferences is a necessary and sufficient condition for uniform commodity taxation to be optimal. See also the discussion in Wilson (1989) of the optimal base for a uniform commodity tax, focusing on which products the tax should cover.

${ }^{3}$ Although tests of separability reported in Barnett and Lee (1985) reject the null hypothesis that separability in preferences holds.

${ }^{4}$ Our analysis differs from other available work on tax evasion and the underground economy, much of which builds on Allingham and Sandmo (1972), and addresses such issues as the conditions for an increase in evasion to occur with increasing tax rates in single consumer models with aversion to risk. See also Watson (1985), Kesselman (1989), and Jung, Snow, and Trandel (1994). More empirically based analysis of tax evasion can be found in Fortin and Fréchelte (1987), and Lemieux, Fortin, and Fréchette (1994). We instead focus on the economy wide effects of base broadening using models that incorporate both tax induced self supply and evasion activities, performing welfare analysis of both overall and individual agent gains and loss. Our approach also represents a departure from previous applied general equilibrium tax analyses (see Shoven and Whalley (1992)) which exclude both of these effects. 
typical base broadening exercise, newly taxed commodities (services, such as haircuts, garden care, house repair) are easier to provide from within the household than is true for previously taxed commodities (manufactures). As a result, tax induced substitution into relatively inefficient household production occurs. In addition, because some of the commodities newly added to the tax base, such as small scale construction, are difficult to tax when provided by small scale suppliers, a further effect is to stimulate underground activities which avoid the tax, but which are again inefficient (at the margin) due to the tax.

We first show how existing welfare analysis of indirect tax base broadening needs to be modified in light of such considerations. Consumption side gains from removing variance in tax rates across consumed products need to be set alongside production side losses from increased tax sheltered production as self suppliable and informally supplied products are brought into the tax base. We present numerical examples of simple general equilibrium models in which substitution between household and market production for previously non taxed goods and services yields welfare worsening base broadening, even with separable preferences. Importantly, consumption side gains from base broadening are largely invariant to the presence of an income tax, since differences in commodity tax rates are what matter; while supply side losses are sharply compounded by the presence of an income tax. Thus we argue that indirect tax base broadening in the presence of an income tax (at OECD levels) will typically be a welfare worsening change.

We also develop a two individual elaboration of these models in which informal (nontaxed) sector activities are undertaken by the poor, who sell their output to the rich in tax free informal sector markets. This model elaboration suggests that, in contrast to traditional analysis, base broadening can be progressive even if efficiency worsening. This result occurs because 
3

informally supplied output is perfectly substitutable for comparable market provided and taxable products, and so the broadened tax operates as akin to a tariff on trade between the rich and the poor in traded informal production. Poor households gain from their ability to sell such products at the gross of tax price, and thus can benefit from base broadening. This is in contrast to conventional analyses which see base broadening as welfare improving and regressive, if products such as food, bought heavily by the poor, are brought into the tax base.

We analyze these possibilities further by presenting a two household model calibrated to 1994 Canadian data. In Canada, a preexisting 131/4\% Manufacturers Sales Tax (MST) was replaced by a 7\% Goods and Services Tax (GST, effectively a VAT) in 1990. Data clearly show a reduction in consumption of substitutable market production (such as restaurant meals) in favour of household production (own consumption of food) following the broadening of the tax base. ${ }^{5}$ Also, Spiro (1993) provides evidence of a tax induced increase in underground activity following the change and Karoleff, Mirus and Smith (1994) report similar effects.

Using calibration techniques, we generate parameter values which, for the central case specification of the model confirm that for the GST base broadening undertaken in Canada in 1990 both the efficiency and distributional effects we indicate above. Information on self supply and underground activity in Canada, as in other countries, is fragmentary and incomplete in both levels and change form, requiring us to design a mixed calibration procedure to identify

\footnotetext{
${ }^{5}$ The Canadian financial newspaper, The Financial Post, for instance, reported on October 17, 1995 that the Canadian Restaurant and Food Services Association advocated that the Canadian GST be extended to food to partially offset the tax incentive for home food preparation. The report indicates that data show that Canadians in 1995 only spent $35 \%$ of their food budget on eating out, in contrast to $42 \%$ in 1990 when the GST was first introduced to also cover restaurant meals.
} 
parameter valves for the model. We then use a different form of calibration compared to previous tax models in which we calibrate not only to a base case equilibrium, as is conventional other in applied general equilibrium literature ${ }^{6}$, but also to data on the changes which actually occurred in the Canadian economy following the base broadening. Even were full information available on changes in self supply and informal market activity in response to the base broadening, such data alone would not be sufficient to infer the sign of the welfare change involved. Some form of model calibration would still be needed to infer parameters on preferences and technology consistent with the available data, and provide a welfare analysis of the tax change.

Sensitivity of model results is present with respect to elasticity values, but results still strongly emphasize the compounding effects of taxes: model analyses of base broadening which incorporate pre-existing income taxes produce significantly larger effects than those which do not. Rethinking the desirability of base broadening in other countries, including developing countries where self supply and informal sector activity are major considerations, may thus also be in order in light of this analysis.

\footnotetext{
${ }^{6}$ See Mansur and Whalley (1984), and Shoven and Whalley (1992).
} 


\section{SELF SUPPLY AND INFORMAL SECTOR RESPONSES TO VAT BASE BROADENING: SOME NUMERICAL EXAMPLES}

That base broadening can be both efficiency worsening and progressive in the presence of self supply and informal sector activity can be demonstrated using simple numerical examples of general equilibrium tax models. Conventional welfare gains follow from the removal of intercommodity distortions as a lower rate tax on all market activity replaces a higher rate tax on a portion of such activity, but counteracting welfare losses come into play through distortions between taxed and non taxed sources of supply as the tax base is broadened (self supply, and the informal sector). Unambiguous theoretical results are not possible since two counteracting effects are involved, but the net welfare effect of base broadening can clearly be negative.

\subsection{A Single Household Example}

A one household model illustrates the simplest case where efficiency losses from VAT base broadening can occur. In this, we use a representation of technology and preferences along with tax parameters, and compute and compare equilibria under narrow and broader tax bases while tax yields are maintained constant in real terms.

We consider a three good model, reflecting goods presently taxed under a narrow base tax (manufacturing, G), goods not taxed under the narrow based tax (services, S), and leisure, L. The single household has a utility function defined over the three goods,

$$
U=U(G, S, L) \text {. }
$$

In numerical simulation $U$ is taken to be a convenient functional form, such as Cobb-Douglas or CES. 
The household has a fixed endowment of time, $\overline{\mathrm{T}}$, which can be allocated to leisure, $\mathrm{T}^{\mathrm{L}}$, non-market activities, $\mathrm{T}^{\mathrm{NM}}$, or market labour supply, $\mathrm{T}^{\mathrm{M}}$, ie.

$$
\bar{T}=T^{L}+T^{N M}+T^{M} \text {. }
$$

Time allocated to market labour supply can be allocated to production of $\mathrm{G}$, or to market production of $\mathrm{S}$,

$$
T^{M}=T^{S}+T^{G} \text {. }
$$

We assume a simple constant marginal product of labour production function for $\mathrm{G}$,

$$
G=\alpha T^{G} \text {. }
$$

For $\mathrm{S}$, we assume that there are two alternative technologies available; one which produces output traded on the market, $\mathrm{S}^{\mathrm{M}}$, and which can be taxed and the other non-market based, and hence non taxable, reflecting self supply, $S^{N} \cdot{ }^{7}$ We assume that market supply $S^{M}$ also has a constant marginal product of labour technology, as with $\mathrm{G}$; while technology for the non-market self supply component is represented by an exponential function, giving an upward sloping supply function,

$$
\begin{aligned}
& S^{M}=\beta T^{S}, \\
& S^{N}=\gamma\left(T^{N M}\right)^{\theta}
\end{aligned}
$$

The supply elasticity for the non-market (self supply) supply function is $\theta /(1-\theta)$. The two identities

$$
\begin{aligned}
& S=S^{M}+S^{N}, \\
& L=T^{L}
\end{aligned}
$$

complete the model.

The effect of a tax only on $\mathrm{G}$, with revenues recycled as income to the consumer, is to reduce consumption of $\mathrm{G}$ and increase consumption of $\mathrm{S}$. Broadening the base of the tax to

${ }^{7}$ Gravelle and Kotlikoff (1989) use a related treatment of multiple production technologies in assessing the incidence and efficiency effects of corporate taxes. 
include $\mathrm{S}$, while maintaining equal yield, results in reduced consumption of $\mathrm{S}$. But because $\mathrm{S}^{\mathrm{M}}$ is taxed while $S^{N}$ is not, production substitutes away from $S^{M}$ towards $S^{N}$, and at the margin additional inefficient production of $S^{\mathrm{M}}$ occurs. Broadening the base of the tax in this case will tend to improve welfare, in so far as it removes a distortion in consumption between $\mathrm{G}$ and $\mathrm{S}$, but will lower welfare in so far as it introduces a distortion in production between $S^{\mathrm{N}}$ and $\mathrm{S}^{\mathrm{M}}$. Even in the presence of separable preferences (Sadka's (1977) condition for optimal commodity taxes to be uniform), base broadening (a move towards uniform taxation) may be welfare worsening.

Table 1 reports an example of welfare worsening base broadening in a one household model which we have solved numerically using GAMS optimization software (see Brooke, Kendrick and Meeraus (1988)). In this example, we have deliberately chosen functional forms and parameter values to generate the result that adverse tax substitution effects in favour of self supply under base broadening are stronger than the consumption side gains from equal tax treatment of $\mathrm{G}$ and $\mathrm{S}$. We specify a CES utility function, other model parameter values $\alpha, \beta$, $\gamma$, and $\theta$, and then implement the model by entering first order conditions for utility and profit maximization as constraints on GAMS optimization, along with the time budget constraint. 


\section{Table 1}

\section{An Example of Welfare Worsening VAT Base Broadening in a One-Household Model}

\section{A. Model Specification}

- Functional Form for CES Preferences:

$$
\delta^{L}=0.55, \delta^{M}=0.15, \delta^{S}=0.3, \sigma=0.5
$$

- $\quad$ Parameter Specification ${ }^{9}$

$$
\alpha=1.0, \beta=1.0, \gamma=4.5, \theta=0.4
$$

- Base Case Tax Rate on G

$$
t_{G}=30 \%
$$

\section{B. Results From Model Incorporating Self Supply}

$\begin{array}{lll} & \begin{array}{l}\text { Equilibrium Under } \\ \text { Narrow Base Tax }\end{array} & \begin{array}{l}\text { Equilibrium Under } \\ \text { Broad Base Tax }\end{array} \\ \text { Utility } & 9.928 & 9.867 \\ T^{M} & 8.6 & 6.9 \\ T^{N M} & 2.7 & 4.0 \\ \text { Tax Rate } & 30 \% \text { (G only) } & 27.3 \% \text { (Equal Yield Tax Rate } \\ & & \text { on G and S) }\end{array}$

\section{Results From A No Self Supply Model}

[CES Preference Function Parameters: $\delta^{\mathrm{L}}=0.84, \delta^{\mathrm{M}}=0.08, \delta^{\mathrm{N}}=0.08, \sigma=0.5$ ]

$\begin{array}{lll} & \text { Equilibrium Under } & \text { Equilibrium Under } \\ & \text { Narrow Base Tax } & \text { Broad Base Tax } \\ \text { Utility } & 10.895 & 10.913 \\ \text { Tax Rate } & 30 \%(\mathrm{G} \text { only) } & \begin{array}{l}14 \% \text { (Equal Yield Tax Rate on } \\ \text { G and S) }\end{array}\end{array}$

${ }^{8} \delta^{\mathrm{L}}, \delta^{\mathrm{M}}, \delta^{\mathrm{S}}$ refers to share parameters on leisure, market goods, and services in the CES preferences; with $\delta$ denoting the elasticity of substitution.

${ }^{9}$ These parameters correspond to the model description in the text. 
We then maximize an objective function (utility in the one household case) subject to the above constraints, and the equilibrium conditions ${ }^{10}$.

In this example, moving from a narrow based to an equal yield broadly based tax results in a fall in utility (Section B Table 1). Time devoted to non market activity $\left(\mathrm{T}^{\mathrm{NM}}\right.$ ) increases, while time devoted to market activity $\left(\mathrm{T}^{\mathrm{M}}\right)$ falls. The substitution effect into self-supply (non market) activity is strong enough in this case, that the tax base contracts to the degree that an equal yield tax rate of $27.3 \%$ is needed to replace a narrow base tax rate of $30 \%$. With no self supply features in the model (Section C, Table 1), base broadening on a comparable equal yield basis instead involves a $14 \%$ replacement tax on $\mathrm{G}$ and $\mathrm{S}$ combined. In this simple case, indirect tax base broadening is welfare worsening rather than welfare improving (the conventional result).

\subsection{A Two Household Example}

We can conduct similar analyses using a two household version of the same model as above, and hence also capture the redistribution between rich and poor which can occur with VAT base broadening. The element of redistribution due to base broadening emphasized here is missing in existing literature, and operates in favour of lower income households rather than against them. VAT base broadening is usually thought to be regressive because high income households save a larger share of their income than lower income households, and spend a

\footnotetext{
${ }^{10}$ Relative to a conventional general equilibrium tax model (Shoven and Whalley (1992), the only complication involves rents associated with the upward sloping supply function for selfsupply activity, and these have to be included as part of income.
} 
smaller fraction of their income on newly taxed products. ${ }^{\prime \prime}$ The emphasis here is on the ability of lower income households to sell informally provided (and hence tax free) goods and services to the rich at the gross of tax rather than net of tax price which applies to comparable market provided goods.

In this elaborated version of the single household model, we distinguish between self supply (own preparation of meals, rather than consumption in restaurants) as well as supply through the informal sector (cash sales by small business which evade tax). We make the assumption that the supply side of the tax free portion of the informal sector is exclusively occupied by the poor, and that the rich are purchasers of tax free informally marketed services alongside perfectly substitutable comparable taxed and market provided services (ie. the rich make no tax free sales in the informal market).

We consider two classes of individuals, rich and poor, each of which has a utility function defined over four goods (rather than three as in the one household model presented earlier)

$$
\begin{aligned}
& U^{R}=U^{R}\left(G^{R}, S_{1}{ }^{R}, S_{2}{ }^{R}, L^{R}\right) \\
& U^{P}=U^{P}\left(G^{P}, S_{1}{ }^{P}, S_{2}{ }^{P}, L^{P}\right)
\end{aligned}
$$

where $S_{1}$ and $S_{2}$ represent the two distinct products involved with self supply on the one hand (restaurant versus home prepared meals), and informal sector activity (including untaxed small scale construction activity) on the other.

Production for $\mathrm{G}$ is as above, i.e.

$$
G=\alpha T^{G}
$$

"See the discussion in Peckman and Okner (1974). This view was later challenged by Browning (1987), but involved a different mechanism to that we stress here. 
where the time input into market good production now includes both that of the rich $\left(\left(\mathrm{T}^{\mathrm{G}}\right)^{\mathrm{R}}\right)$, and the poor $\left(\left(T^{G}\right)^{P}\right)$.

$$
T^{G}=\left(T^{G}\right)^{P}+\left(T^{G}\right)^{R} \text {. }
$$

For the self supplied good, the technology remains unchanged i.e. for the market portion,

$$
S_{1}^{M}=B_{1} T_{1}^{S}
$$

where both rich and poor both supply time input into production, i.e.

$$
T_{1}^{S}=\left(T_{1}^{S}\right)^{P}+\left(T_{1}^{S}\right)^{R}
$$

In contrast to the one household model, there are now two (rich and poor) non-market supply functions,

$$
\begin{aligned}
& \left(S_{1}^{N}\right)^{R}=\gamma_{1}^{R}\left[\left(T_{1}^{N M}\right)^{R}\right]^{\theta_{1}^{R}} \\
& \left(S_{1}^{N}\right)^{P}=\gamma_{1}^{P}\left[\left(T_{1}^{N M}\right)^{p}\right]^{\theta_{1}^{n}}
\end{aligned}
$$

Market clearing in $S_{1}$ requires that, in equilibrium,

$$
S_{1}^{R}+S_{1}^{P}=S_{1}^{M}+\left(S_{1}^{N}\right)^{R}+\left(S_{1}{ }^{N}\right)^{P}
$$

For the informal sector, we assume that its output $\left(\mathrm{S}_{2}\right)$ is distinct from that represented by self supply $\left(\mathrm{S}_{1}\right)$ ie. small scale construction activity differs from home made jam. Production by rich households sold in this market segment is taxed, and occurs within the formal segment of the economy. Informal sector supply by poor households goes untaxed.

We represent this structure as,

$$
S_{2}^{M}=\beta_{2}\left(T_{2}^{S}\right)^{R} \quad \text { (Market Supply Functionof the Rich) }
$$

i.e. the market supply function of the rich reflects constant marginal product of labour, and

$$
S_{2}^{N}=\gamma_{2}^{\prime \prime}\left[\left(T_{2}^{N M}\right)^{n^{\prime}}\right]^{0_{2}^{\prime \prime}} \quad \text { (Informal Sector Supply Function of the Poor) }
$$

i.e. the supply function for untaxed informal sector output by the poor is upward sloping.

As before, the two households each face time budget constraints

$$
\bar{T}^{p}=\left(T^{L}\right)^{p}+\left(T^{M}\right)^{p}+\left(T_{1}^{N M}\right)^{p}+\left(T_{2}^{N M}\right)^{p}
$$




$$
\bar{T}^{R}=\left(T^{L}\right)^{R}+\left(T^{M}\right)^{R}+\left(T_{1}^{N M}\right)^{R}
$$

where

$$
\left(T^{M}\right)^{p}=\left(T_{1}^{s}\right)^{p}+\left(T^{G}\right)^{p}
$$

and

$$
\left(T^{M}\right)^{R}=\left(T_{1}^{S}\right)^{R}+\left(T_{2}^{S}\right)^{R}+\left(T^{G}\right)^{R} \text {. }
$$

The model is completed by the demand supply equalities for $G, S_{1}$, and $S_{2}$

$$
\begin{aligned}
& G=G^{R}+G^{P}=\alpha\left[\left(T^{G}\right)^{P}+\left(T^{G}\right)^{R}\right] \\
& S_{1}=S_{1}^{R}+S_{1}^{P}=\beta_{1} T_{1}^{S}+\delta_{1}^{R}\left[\left(T_{1}^{N M}\right)^{R}\right]^{\theta_{1}^{R}}+\delta_{1}^{P}\left[\left(T_{1}^{N M}\right)^{p}\right]^{\theta_{1}^{P}}
\end{aligned}
$$

and

$$
S_{2}=S_{2}{ }^{P}+S_{2}^{R}=\left(S_{2}^{N}\right)^{R}+\left(S_{2}^{M}\right)^{P}=\beta_{2}\left(T_{2}^{S}\right)^{R}+\gamma_{2}^{p}\left[\left(T_{2}^{N M}\right)^{P}\right]^{\theta_{2}^{\prime \prime}}
$$

A version of Walras Law applies to this economy, involving the trades in $G, S_{1}$, and $S_{2}$ across the two individuals.

\section{Defining}

$$
E D^{G}=G^{R}+G^{P}-\alpha\left[\left(T^{G}\right)^{P}+\left(T^{G}\right)^{R}\right]
$$

and,

$$
\begin{aligned}
& E D^{S_{1}}=S_{1}^{R}+S_{1}^{P}-\beta_{1} T_{1}^{S}-\delta_{1}^{R}\left[\left(T_{1}^{N M}\right)^{R}\right]^{\theta_{1}^{R}}-\delta_{1}^{P}\left[\left(T_{1}^{N M}\right)^{P}\right]^{\theta_{1}^{P}} \\
& E S^{S_{2}}=S_{2}^{R}+S_{2}^{P}-\beta_{2}\left(T_{2}^{S}\right)^{R}-\gamma_{2}^{P}\left[\left(T_{2}^{N M}\right)^{P^{P}}\right]^{\theta_{2}^{P}}
\end{aligned}
$$

it follows that

$$
P^{G} E D^{G}+P^{1} E D^{S_{1}}+P^{2} E S^{S_{2}}=0
$$

where $\mathrm{P}^{\mathrm{G}}, \mathrm{P}^{1}$, and $\mathrm{P}^{2}$ are the market clearing prices for $\mathrm{G}, \mathrm{S}_{1}$, and $\mathrm{S}_{2}$. With the constant marginal product production functions as specified $((10)$ and $(14))$, if the wage rate is unity, $\mathrm{P}^{\mathrm{G}}=\alpha, \mathrm{P}^{\prime}$ $=B_{1}$, and $P^{2}=\beta_{2}$.

As with the one household model, this model can also be modified to incorporate indirect taxes, and used to evaluate the effects of base broadening. Broadening the base of indincel laxes 
from $G$ to also include $S_{1}$ and $S_{2}$, while maintaining equal yield, leads to a reduction in consumption of $S_{1}$ and $S_{2}$, and also substitution into both non taxed self supply and informal sector activities. But because informal activities on the production side by the poor go untaxed, a transfer to the poor from the rich occurs as they sell informal sector product at gross of tax prices to the rich. In this model, base broadening can thus be pro poor as well as welfare worsening.

Table 2 reports an example using this model which yields this result. Here, the preference parameter values are the same for the two individuals, but technology differs as above. The result is that VAT base broadening is welfare worsening, and because the poor are sellers of informally provided products and the rich are buyers, there is a gain to poor households and a loss to the rich household. A $20 \%$ narrow based tax on $\mathrm{G}$ is replaced by an equal yield broadly based tax on market supplied $\mathrm{G}, \mathrm{S}_{1}$, and $\mathrm{S}_{2}$ of $9 \%$. The utility of the rich falls from 9.711 to 9.614 as base broadening occurs, while the utility of the poor rises from 7.569 to 7.576 . Based on an aggregate welfare criterion of the sum of utilities, base broadening is a welfare worsening change in this case. The changes in market time, self supply and the informal sector for the rich are not large in this case, but for the informal sector where tax induced inefficient additional production by the poor occurs they are pronounced.

These two examples, however, provide no empirical basis for determining the exact outcome of VAT base broadening in practice. This is what we turn to in the next section. 


\section{Table 2}

\section{An Example of Welfare Worsening But Pro Poor VAT Base Broadening in a Two Household Model}

\section{A. Model Specification}

- Functional Form for Preferences for each Household: CES

- Parameter Specification in Preferences

$$
\begin{array}{ll}
\text { Rich }^{1} & \delta^{L}=0.25, \delta^{M}=0.25, \delta^{S_{1}}=0.25, \delta^{S_{2}}=0.25, \sigma=0.83 \\
\text { Poor }^{1} & \delta^{L}=0.25, \delta^{M}=0.25, \delta^{S_{1}}=0.25, \delta^{S_{2}}=0.25, \sigma=0.83 \\
\text { Production }^{2} & \alpha=1, \beta_{1}=1, \beta_{2}=1, \gamma_{1}=1.25, \theta_{1}=0.8, \gamma_{2}=1.8, \theta_{2}=0.8
\end{array}
$$

\begin{tabular}{|c|c|c|c|c|c|c|c|}
\hline$(\%)$ & $\begin{array}{l}\text { Utility } \\
\text { of the } \\
\text { Rich }\end{array}$ & $\begin{array}{l}\text { Utility } \\
\text { of the } \\
\text { Poor }\end{array}$ & $\left(\mathbf{T}^{\mathrm{M}}\right)^{\mathrm{R}}$ & $\left(\mathrm{T}^{\mathrm{M}}\right)^{\mathrm{P}}$ & $\left(T_{1}^{S}\right)^{R}$ & $\left(T_{1}{ }^{S}\right)^{P}$ & $\left(T_{2}^{S}\right)^{P}$ \\
\hline $\begin{array}{l}\text { Narrow } \\
\text { Tax Base }\end{array}$ & 9.711 & 7.569 & 21.5 & 7.4 & 1.7 & 1.7 & 4.9 \\
\hline $\begin{array}{l}\text { Broad Tax } \\
\text { Base }\end{array}$ & 9.614 & 7.576 & 21.0 & 4.3 & 1.9 & 1.9 & 7.6 \\
\hline
\end{tabular}

$\begin{array}{ll}\text { - } & \text { Base Case Tax Rate on } \mathrm{G} \\ \text { Equal Yield Tax Rate on } & 20 \% \\ \mathrm{G}, \mathrm{S}_{1}, \mathrm{~S}_{2} & 9 \%\end{array}$

\section{B. Results}

${ }^{\prime} \delta^{\mathrm{l}}, \delta^{\mathrm{M}}, \delta^{\mathrm{S} 1}, \delta^{\mathrm{S} 2}$, refer to share parameters on leisure, market goods, self suppliable goods $\left(\mathrm{S}_{1}\right)$, and informal sector goods $\left(\mathrm{S}_{2}\right)$ in the CES preferences; $\delta$ denotes the elasticity of substitution in preferences.

2 These parameters correspond to the model description in the text. 


\section{EMPIRICAL APPLICATION OF THE MODEL TO BASE BROADENING IN CANADA}

We have used the models set out in the previous section to empirically evaluate the welfare impacts of the base broadening in indirect taxes which occurred in Canada in the early 1990's. We choose the Canadian case, both because the form of base broadening which occurred exactly parallels the model structure set out above, and because the resulting debate on what have been the effects of the base broadening exercise in Canada has focused on those features discussed here: induced evasion through the informal sector, and increased self supply. Much of this debate has been over the forgone revenue effects of the tax change due to these effects (see Spiro (1994)), rather than over efficiency and distributional consequences.

Canada introduced a VAT (GST) in 1990 at a $7 \%$ rate in place of a preexisting manufacturer's level tax which only covered around $30 \%$ of consumption ${ }^{12}$ and involved a statutory $13 \frac{1}{4} \%$ tax rate. The stated government objective was to harness gains by broadening the base and lowering the rate, as well as removing various biases against exports and investment in the preexisting tax..$^{13}$

The nature of this base broadening exercise clearly fits the earlier analysis, and so we are able to use numerical general equilibrium analysis to analyze the change. However, the task is somewhat different from that undertaken in the more usual exante or counter factual general equilibrium analysis of tax changes as set out in Shoven and Whalley (1992). In conventional analysis, calibration of a model (structure plus functional forms) to a complete benchmark

\footnotetext{
${ }^{12}$ See Whalley and Fretz (1990) p. 30.

${ }^{13}$ See Government of Canada (1987). In somewhat emotive language the old tax was labelled as a "silent killer of jobs" by the then Finance Minister, due to its cascading features.
} 
equilibrium data set is used, with the benchmark data usually taken as representative of an actual economy contemplating a tax policy change. Information on the expost impact of the tax change is typically unavailable, and is not taken into account in such exercises. In the analysis here, since the tax change occurred in 1990 , information is available on both the pre and post tax change behaviour in the Canadian economy, and is available to be used in evaluating changes in welfare implied by the data associated with the policy change.

We thus use a mix of level and changes calibration for our model, calibrating it to a base year which is after the tax change has occurred (1994), and using information on the behaviourial response to base broadening to infer relevant model elasticities. The conventional calibration procedure $^{14}$ in applied general equilibrium models, often referred to as levels calibration, only uses data at a point in time, the benchmark year. This is typically taken as the reference point to which calibration is performed. With CES functions, such calibration generates share parameters once substitution elasticities have been selected (usually involving a literature search), determining underlying model parameter values for preferences and technology consistent with the data. Here we calibrate not only to 1994 levels data, but also to information on the response of self supply and informal sector activity. This enables us to use the calibrated parameters to calculate the welfare and distributional impacts of the VAT base broadening which occurred earlier in 1990 , given that the welfare changes are not directly observable.

Our levels data set uses estimates of wages, salaries, and supplementary labour income for 1994 from Canadian National Accounts sources (Table 5, p.28, Statistics Canada, 1994). These provides a measure of market provided $\mathrm{G}, \mathrm{S}_{1}$, and $\mathrm{S}_{2}$. We break this down into component

${ }^{14}$ Also see the recent discussion of calibration in Hansen and Heckman (1996). 
parts by first using the estimate from Drummond et. al. (1994) that the sectors in Canada that are most susceptible to tax evading informal sector activity constituted $11 \%$ of GDP in $1992 .^{15}$ This gives an estimate of market provided $\mathrm{S}_{2}$. We then use government estimates, mentioned earlier, of the fraction of consumption (typically manufactures and non self-suppliable) not covered by the preexisting Manufacturers Sales Tax (MST) to give market provided $\mathrm{S}_{1}$ and $\mathrm{S}_{2}$ combined. Deducting the estimate for $S_{2}$ gives $S_{1}$.

We then use estimates of the size of the underground economy in Canada to construct an estimate of non-market supplied $\mathrm{S}_{2}$. These estimates have high variance. Karoleff, Mirus and Smith (1994) put the size of the underground economy in Canada at between $14 \%$ and $22 \%$ of GDP in 1990 using the so-called monetary approach. An alternative cash demand based estimate by Spiro (1994) is between 8 and $11 \%$ of GDP. However, both of these estimates are strongly criticized by Drummond et. al. (1994) as substantially upward biased; their upper bound is $4.2 \%$ of GDP. ${ }^{16}$ In light of this range, we use a central case estimate of non-market supplied $\mathrm{S}_{2}$ of $10 \%$ of GDP, which is a considerably larger portion of the activity of the poor who are the sole providers of such activity in the model.

To estimate leisure consumption, we use time use survey data for Canada reported in Frederick (1995) which gives data for 1992 for a sample of approximately 7,000 individuals

\footnotetext{
${ }^{15}$ Drummond (et. al.) (1994) itemize these sectors as New Home Construction, Alterations and Improvements, Alcoholic Beverages, Tobacco Products, Motor Vehicle Repair, Used Motor Vehicles, Alcoholic Beverage Service, Child Care outside the home, Hairstyling, Watches and Jewellery, Child Care in home, Miscellaneous House Service, Lodging Paid, Domestic Services, Moving and Storage, Taxi, Board Paid, Upholstery and Furniture, Dressmaking Repair and Alterations, Watches and Jewellery, Shoe Repair.

${ }^{16}$ See also the extensive discussion of the size of the underground economy in Canada in Statistics Canada (1994).
} 
differentiated by age, and socioeconomic status (but not income). For the entire sample, the average hours of paid work per day (averaged over 7 days) were 3.6 hours, compared to leisure ${ }^{17}$ hours of 5.7 hours. This ratio, when applied to market supplied time, yields leisure consumption in aggregate. The same data source reports equal time per day devoted to paid and unpaid work $^{18}$ (3.6 hours/day), and in our benchmark data set, we treat time devoted to nonmarket self supply activity as equal to the value of market provided labour.

Disaggregating this data into rich and poor households is difficult because of the absence of any income breakdown in the Canadian Time Use Survey data. We instead rely on reported differences in activities between individuals stratified by income in a survey of tax evading underground activities collected in Quebec City in 1986, and both reported on and used by Lemieux, Fortin, and Fréchette (1994). Their data clearly show high income individuals as accounting for the majority of purchases of goods from the underground economy, with the majority of sales coming from lower income individuals. They also provide estimates of hours and earnings in the underground economy by income.

We characterize the poor as accounting for the bottom $30 \%$ of households in Canada, who receive $10 \%$ of labour income originating from market activity. Given the differences in hours of paid work between fulltime workers and the not employed category in the time use survey,

${ }^{17}$ Leisure includes socializing; television, reading and other passive leisure; sports, movies and other entertainment events; and active leisure. It does not include sleeping, eating meals, or washing, dressing, naps, religious activities, all of which are included in the larger category of "personal care" and occupy an average 10.5 hours/day. See Frederick (1995), pp. 65-66.

${ }^{18}$ This category includes cooking and washing up; housekeeping; maintenance and repair; shopping; childcare; and other household work (including gardening and household administration (bills)). 
we assume that $75 \%$ of leisure time is consumed by the rich. Following Lemieux et. al. (1994), we assume the rich buy substantially more than their own market production of the informally supplied good. We also allocate non-market self supply activity $1 / 3$ to the poor, and $2 / 3$ to the rich.

These data, with the adjustments and assumptions as detailed above and in the footnotes to Table 3, have been used to produce a 1994 microconsistent benchmark equilibrium data set which is used in model calibration. In this data set, market activity appears as a significant, but still only a minor portion of total activity in the economy (a reflection of the time use survey data); the poor produce and sell informal sector product to the rich; and data are adjusted to reflect the existing 1994 GST.

To use this data set for model calibration purposes, we also need to specify substitution elasticities in preferences, as well as the units and exponent terms in the self and informal supply functions (rich and poor for self-supply, and poor for informal). This involves the changes portion of our model calibration. We use two estimates of relevant impacts of the GST change from which we infer these parameter values.

The first is evidence on self supply responses to the tax change. After the introduction of the GST, the percentage of food dollars spent on restaurant meals as against home prepared meals fell from $42 \%$ to $35 \%$ (Canadian Restaurant Association (1994)). Taking this as 
Table 3

1994 Canadian Benchmark Data Used in Model Calibration" (\$bill, 1994)

\section{A. Production Data}

$\underline{\text { Goods }}$

Exclusively Market Provided

Self Suppliable

Informal Sector Provided

Leisure

TOTAL

B. Consumption Data

Goods

Self Suppliable

Informal Sector Provided

Leisure

TOTAL

C. Budget Constraints by Household

Time Supplied to Market Production

Time Supplied to Non Market

Production (Including Leisure)

Rent

Transfers

TOTAL
Exclusively Market Provided

\section{Market Based \\ Production}

$224.1^{3}$

$102.8^{4}$

$82.2^{2}$

$\frac{0.0}{409.1^{1}}$

$\underline{\text { Rich }}$

Poor

$36.5^{12}$

$178.4^{13}$

$19.7^{11}$

161.9

396.6

1121.0

$148.1^{11}$

485.8

\section{Rich}

Poor

$368.2^{14}$

$40.9^{14}$

$591.5^{15}$

$237.1^{15}$

$158.5^{16}$

$92.8^{16}$

$2.9^{1}$

$25.8^{17}$

396.6

1121.5

"This reflects a $7 \%$ GST present in the benchmark data.
Total

Production

224.1

$455.0^{7}$

162.1

$647.7^{6}$

1465.9

Total (Gross of Tax)

$239.8^{10}$

$462.2^{10}$

$167.9^{10}$

647.7

1517.6

Total

409.1

828.6

251.3

28.6

1517.6 


\section{Notes to Table 3}

1. This is wages, salaries, and other supplementary labour income from the 1994 Canadian National Accounts, Table 1, p.15. 1994 Canadian GNP at market prices is $\$ 747.3$ bill (same table).

2. This is $11 \%$ of 1994 Canadian GNP (see footnote 1 above). The $11 \%$ estimate is from Table 2, p. 4, Drummond et al (1994).

3. This is $30 \%$ of 1994 Canadian GNP (see footnote 1), reflecting a taxed (self suppliable informal sector provision) portion of activity under the former Manufacturers Sales Tax (MST) of 30\%. This was the Canadian government estimate of taxable consumption under the MST, as discussed in Fretz and Whalley (1991).

4. This is determined by residual.

5. This reflects an assumed ratio of the size of the Underground economy to GDP (Wage Bill) of $10.0 \%$, of following Smith et al (1994), Spiro (1994), and Drummond et al (1994) ratios of GDP/Underground.

6. This reflects the hours per day ratio of Leisure/Paid Work of 5.7/3.6 for the whole 1992 sample. Table IA, As Time Goes By, Frederick (1995).

7. This reflects the equal hours per week of paid and unpaid work for the whole 1992 time use survey sample (Table 1A, As Time Goes By, Frederick (1995)).

8. Canadian time use survey data do not report information separately by income. They do, however, show daily consumption of 4.7 hours of leisure compared to 5.4 hours for part-time workers (Table 1A, As Time Goes By, Frederick (1995)), but to use this to determine leisure consumption by rich and poor, wage rate data for a reasonable rich - poor clarification would be required. This is not available in this form. This time use data supports an (approximate) allocation which we use of $75 \%$ of leisure time by the rich, given that wage rate differentials will raise the share of leisure in value terms consumed by the rich.

9. These are allocated between rich and poor proportional to consumption of leisure.

10. This is gross of a GST rate of $7 \%$.

11. This reflects an allocation of aggregate expenditures on informally providable output drawing on data in Lemieux, Fortin, and Frechette (1994). They report survey data for a sample of respondents from Quebec City to a questionnaire on underground market activity. By annual income range, date are reported on purchases from the underground economy in \$ per respondent by range. Taking the top two ranges to reflect rich households, and bottom two poor households, a ratio of purchases of approximately $5 / 2$ is implied. Correcting from per capita data to the distribution of population by rich and poor we assume gives our allocation. These data refer in the model to both market and non market purchases, unlike in Lemicux et al.

12. These are allocated by rich and poor using money incomes (labour income plus transfers).

13. These reflect a residual calculation.

14. We assume that the rich (non poor) represent $70 \%$ of the Canadian population, but receive $90 \%$ of market labour income

15. These are determined by residual from non market based production costs, once rents are known.

16. These are implied by the assumed values of supply elasticities in the model in non market self supply and informally provided sectors (sce discussion text).

17. These refer to redistributed tax revenues. We assume that $90 \%$ of these are returned to the poor, and $10 \%$ to the rich. 
representative of all self-supply activity, implies a $10 \%$ change in self supply in response to a $7 \%$ relative price change (the new broadened GST tax rate on introduction in 1990). This, in turn, implies an own price supply elasticity of 1.5 . Given that the supply elasticity in (6) equals $\theta /(1$ $\theta$ ), we use a value of $\theta$ of 0.6 in the self supply production functions in the model.

The second piece of evidence is provided by the estimate due to Spiro (1994) that in 1992 the increase in the size of the underground economy attributable to the GST was $\$ 5.7$ bill. Given an underground economy in Table 1 of $\$ 65$ bill., this implies a percentage supply response of a little under $10 \%$ following a $7 \%$ tax rate change. This implies also a supply elasticity of approximately 1.5 , and a $\theta$ value in informal sector activity of 0.6 .

The values of $\gamma$ in the self supply and informal sector production functions are obtained by direct substitution of the values for outputs and inputs from the benchmark data set in Table 3 into equations (15), (16), and (18), given the values for $\theta$ in this way.

For the elasticity of substitution in consumption, we use a value of 0.8 to reflect the ease of substitution between exclusively market based, and self suppliable and informally sector supplied products. The estimate we use draws on that obtained by Greenwood, et. al. (1995) in real business cycles research of 0.79 for the U.S. They also report slightly higher elasticities for men (around 1.0) and for women (1.5) in later estimation work for consumption substitution between home and market goods for the US. The value chosen for this elasticity in the model affects the size of the consumption side gains from base broadening, and hence sensilivity analysis is performed around this value.

Table 4 presents the results from simulations using the model in which the GST as it operated in 1994 is replaced by an equal yield narrow based sales tax on manufactures (G). 
Table 4

Model Results for the Replacement of a Broadly Based Sales Tax (VAT or GST) in Canada by Narrow (Manufacturers) Sales Tax (Welfare Impacts Using Hicksian Measures in \$1994, bill).

\section{Central Case}

\begin{tabular}{lccc} 
& Poor & Rich & $\begin{array}{c}\text { Total } \\
\text { (Sum of Rich \& Poor) }\end{array}$ \\
Hicksian Equivalent Variation & -0.194 & 0.371 & 0.177 \\
Hicksian Compensating & -0.189 & 0.365 & 0.176 \\
Variation & & & \\
Equal Yield Tax Rate & \multicolumn{1}{c}{$13.24 \%$} &
\end{tabular}

\section{Table 5}

Impacts of Replacing Preexisting Narrow by Broad Based Sales Tax in Canada in the Presence of an Income Tax (Hicksian Welfare Measures in 1994, \$bill)

A.Income Tax Rate $=10 \%$

(11.14\% Equal Yield Sales Rate on

a Narrow Base)

B.Income Tax Rate $=20 \%$

(9.15\% Equal Yield Sales Rate on a Narrow Base)
Hicksian EV

Hicksian CV

Rich
Poor
Total

6.24

6.12

$-2.70$

3.46

3.43

Hicksian EV

Hicksian CV

Rich

11.96

11.72

Poor

$-5.38$

$-5.23$

Total

6.57

6.49 
Here, a gain of around $\$ 0.17$ billion results from reverting to the narrow tax base, with the rich gaining and the poor losing. An equal yield tax rate of $13.24 \%$ applies in the model simulations for the narrow based tax; virtually the same as the 1990 statutory rate. This result has the same implication as shown in the previous numerical examples, namely that base broadening in Canadian indirect taxes proved to be a welfare worsening but pro poor tax change.

Table 5 presents results for similar experiments but in the presence of different levels of an assumed preexisting income tax (assumed zero in the analyses in Table 4). As the income tax rate in the base case rises, then so do aggregate gains from reversing base broadening by returning to a narrow based tax, and these effects are also an increasing function of the tax rate. Gains are concentrated on the rich where, in terms of size, the majority of self supply activity occurs. These results occurs for the reasons mentioned earlier. Consumption side gains from base broadening occur reflect a reduced variance of tax rates on marginal consumption of taxed goods, while production side losses reflect combined sales and income tax level effects. The sales tax broadening effect on the production side increases with a larger preexisting income tax and hence aggregate gains from unwinding base broadening rise sharply with the income tax rate.

Table 6 presents sensitivity analyses of model results with respect to key model parameters. There is substantial sensitivity with respect to demand side elasticity parameters, and less so to production side elasticities. With demand side elasticities of 1.5 , demand side gains dominate production side effects to the extent that both rich and poor lose, with aggregate loses from reverting to a narrow based tax. With demand side elasticities of 0.5 , production side effects dominate, and aggregate gains occur. However, the rich gain sharply more than the poor; and in relative terms, the tax change of moving back to a narrow tax remains pro rich. 
Production side elasticity sensitivity is less; overall welfare gains to the rich and losses to the poor prevail. All these effects, however, remain small compared to the added effects of the income tax, which dominate these sensitivity variations.

\section{Table 6}

Sensitivity of Table 4 Results with respect to Key Model Parameters

(Hicksian Welfare Measures in 1994, \$bill.)

$\begin{array}{lcccccc} & \mathrm{CV}^{\mathrm{R}} & \mathrm{CV}^{\mathrm{P}} & \mathrm{EV}^{\mathrm{R}} & \mathrm{EV}^{\mathrm{P}} & \mathrm{CV} & \mathrm{EV} \\ & & & & & \text { Total } & \begin{array}{c}\text { Total } \\ \text { 1.Central Case }\end{array} \\ \text { 2.Demand Side Elasticity }=0.5 & 0.365 & -0.189 & 0.371 & -0.194 & 0.176 & 0.177 \\ \text { 3.Demand Side Elasticity =1.5 } & -0.596 & -0.199 & 0.605 & -0.204 & 0.397 & 0.401 \\ \text { 4.Self Supply Side Elasticities =1.0 } & 0.555 & -0.185 & -0.321 & -0.190 & -0.501 & -0.511 \\ \text { 5.Self Supply Side Elasticities }=2.0 & 0.269 & -0.221 & 0.273 & -0.227 & 0.049 & 0.046\end{array}$




\section{CONCLUSION}

This paper discusses the effects of base broadening in indirect taxes, such as VAT, in the presence of self supply and informal sector activity. Advocacy of such base broadening is usually based on implicit models which assume separability of preferences in which uniform commodity tax rates on all non leisure goods are optimal. Where optimal non-uniform commodity tax rates have been calculated before, such as by Deaton (1981), they only take into account cross price effects in preferences between leisure and non leisure goods, not the effects we stress here.

We suggest that, contrary to currently received wisdom, typical base broadening in a sales tax from one covering only manufactures to one covering all goods and services can be simultaneously welfare worsening and pro poor, since additional distorting margins which do not apply to the narrow tax base have to be taken into account. Significant effects from base broadening, in terms of increased supply of self-suppliable products, such as consumption of own prepared food over restaurant meals, and in response of the underground economy to broadening of the sales tax base have been empirically documented. The latter is discussed by Spiro (1993) for Canada following the GST (VAT) introduction in 1990. Tax induced increases in underground sector activity, and in self-supply, from base broadening, suggest that different models for the analysis of the impact of VAT base broadening are needed relative to those conventionally used. We also stress the role that transfers between the rich and the poor associated with such tax changes can play, if the poor sell tax free informal sector production to richer households behind the implicit tariff protection associated with the broadened tax on market activities in self-suppliable products. 
We develop simple general equilibrium models which capture these features, and use them numerically to assess Canadian base broadening from the Manufacturers Sales Tax to a VAT in 1990. We adopt a different calibration procedure from that used in previous general equilibrium tax models. In this we calibrate not only to levels data as is conventionally done in the literature, but to a combination of levels and change data. The results of the calibrated model suggest that the experience with indirect tax base broadening in Canada in the early 1990's proved welfare worsening in aggregate, but with gains to the poor and losses to the rich, not vice versa as often presumed. These results suggest that conventional wisdom on the impact of indirect tax base broadening might have to be rethought. Importantly, we also show that the losses from base broadening increase significantly once preexisting income taxes are brought into the analysis. This is because consumption side gains from base broadening are from a removal of variance of tax rates on marginal consumption, while production side losses compound (at the margin) with income tax rates. 


\section{BIBLIOGRAPHY}

Allingham, M.G. and A. Sandmo (1972). "Income Tax Evasion: A Theoretical Analysis," Journal of Public Economics, November, 1 (3-4), pp. 323-338.

Barnett, W.A. and Y.W. Lee (1985). "The Global Properties of the Miniflex Laurent, Generalized Leontief, and Translog Flexible Functional Forms," Econometrica, November, Vol. 53, No. 6, pp. 1421-14238.

Brooke, A., Kendrick, D., and Meeraus, A. (1988). GAMS - A Users Guide, San Francisco, Scientific Press.

Browning, E.K., (1978). "The Burden of Taxation", Journal of Political Economy, Vol. 186, August, pp. 649-672.

Canadian Restaurant Association (1994).

Deaton, A. (1981). "Optimal Taxes and the Structure of Preferences", Econometrica, Vol. 149, No.5, pp. 1245-1260.

Drummond, D., M. Ethier, M. Fougere, B. Girard, and J. Rudkin (1994). "The Underground Economy: Moving the Myth Closer to Reality", Canadian Business Economics, Vol. 2, No. 4 , pp. 3 - 17 .

Fortin, B. And Fréchette P. (1987). "The Size and Determinants of the Underground Economy in Quebec" Mimeo, Université Laval, 1987.

Frederick, J.A. (1995). As Time Goes By..Time Use of Canadians, Statistics Canada, Ottawa.

Gravelle, J.D. and L.J. Kotlikoff (1989). "The Incidence and Efficiency Costs of Corporate Taxation When Corporate and Non Corporate Firms Produce The Same Good", Journal of Political Economy, Vol. 97, August, pp. 749-780.

Government of Canada (1987). Tax Reform 1987: Sales Tax Reform, Department of Finance.

Greenwood, J., Rogerson R., Wright R. (1995). "Household Production in Real Business Cycle Theory", in Cooley T. (eds.), Frontiers of Business Cycle Research, pp. 157-174, Princeton University Press.

Hamilton, R., and J. Whalley (1989). "Reforming Indirect Taxes in Canada: Some General Equilibrium Estimates", Canadian Journal of Economics, Vol. XXII, No. 3, August, pp. $561-575$. 
Hansen, L.P. and J.J. Heckman (1996). "The Empirical Foundations of Calibration," Journal of Economic Perspectives, Vol. 10, No. 1, pp. 87-104.

Jung, Y.H., A. Snow and G.A. Trandel (1994). "Tax Evasion and the Size of the Underground Economy," Journal of Public Economics 54, pp. 391-402.

Karoleff, V., R. Mirus and R.S. Smith (1994). "Canada's Underground Economy Revisited: Update and Critique," Canadian Public Policy Vol. XX, No. 3, pp. 235-252.

Kesselman, J. (1989). "Income Tax Evasion: An Intersectoral Analysis" Journal of Public Economics, March 38 (2), pp. 137-182.

Lemieux, T., B. Fortin and P. Fréchette (1994). "The Effect of Taxes on Labour Supply in the Underground Economy," American Economic Review Vol. 84, No. 1, pp. 231-254.

Mansur, A.H. and J. Whalley (1984) "Numerical Specification of Applied General Equilibrium Models: Estimation, Calibration, and Data" in H.E. Scarf and J.B. Shoven (eds.) Applied General Equilibrium Analysis, Cambridge: Cambridge University Press.

Peckman, J.A., \& B. Okner (1974). Who Bears the Tax Burden?, Brookings Institution, Washington.

Piggott, J.R. and J. Whalley (1996). "The Tax Unit and Household Production" Journal of Political Economy, Vol. 109, No. 2, April, pp. 398 - 418.

Sadka, E. (1977)). "A Theorem on Uniform Taxation," Journal of Public Economics, Vol 7(3), pp. 387-391.

Shoven, J.B. and J. Whalley (1992). Applying General Equilibrium. Cambridge University Press.

Spiro, P.S. (1993). "Evidence of a Post-GST Increase in the Underground Economy," Canadian Tax Journal Vol. 41, No. 2, pp. 247-258.

Spiro, P. (1994). "The Underground Economy: Towards a More Balanced View of Alternative Methodologies", Canadian Business Economics, Vol. 2, No. 4., pp. 18 - 21.

Statistics Canada (1994). The Size of the Underground Economy in Canada, Studies in National Accounting, Ottawa.

Watson, H. (1985). "Tax Evasion and Labour Markets," Journal of Public Economics 27, pp. 231-246. 
Whalley, J. and D. Fretz (1990). The Economics of the Goods and Services Tax, Canadian Tax Paper No. 88, Canadian Tax Foundation, 1990.

Wilson, J.D. (1989). "On the Optimal Tax Base For Commodity Taxation," American Economic Review, December, pp. 1196-1206. 